\title{
LARRY ALBERT MORGOTCH: IN MEMORIAM
}

FRANK A. SWITZER, 1301 Shannon Road, Regina, Saskatchewan, S4S 5K9.

Larry Morgotch was one of those rare people who in a quiet and unassuming way manage to influence the ideas of others. Few who knew him well were not in some way influenced by his philosophy of life and nature. Larry used a doublebarrelled approach. If he couldn't persuade you with words he would do it with pictures. Past issues of the Blue Jay contain both articles and pictures by this observant and quietly persuasive naturalist.

Larry was born at Hyas, Saskatchewan, into a farming family, at a time when people were somehow much closer to the land than most are now. During his "growing up" years he developed an interest in natural history. During this time he made several trips into the Porcupine Hills with his father and friends. One such trip, which he recounted most vividly, was made in a wagon drawn by a Fordson tractor. The trail was arduous, many fallen trees had to be cleared and some boggy spots required the building of a corduroy road. Though the trip was ostensibly for fishing purposes, Larry said he was intrigued with the difference in the country. There were different birds, animals and plants all around. The appeal this upland held for him prompted him in later years to take a job in the hills as patrolman with the Department of Natural Resources.

I was fortunate to accompany Larry on a trip to these hills. Though they were not entirely strange to me, I gained new insight into the history and wildlife of the area through that brief visit with Larry.
People often find it strange that someone can have two interests that are widely divergent. Larry was a well-trained and skilful mechanic as well as being a knowledgeable naturalist. His mechanical training was obtained at the Moose Jaw Technical School. He moved to Yorkton in 1955 and in subsequent years worked for several garages and automotive dealerships before he took up a service station franchise in 1967. Since 1970 he operated the Downtown Gulf service station. His customers will miss his integrity and mechanical skill as much as his naturalist friends will miss his skill as a keen and astute observer of wildlife.

In 1966 Larry married Delores Procyshen of Yorkton.

Larry was interested in natural history in a very broad sense. He was not just a bird or animal counter, but an observer of nature. He possessed a very keen eye, probably due to a hearing disability he suffered from. The fact that he saw a particular species of bird or animal was not enough for him. He would spend considerable time sitting and watching what he saw, trying to find out how it related to its habitat and environment. He was not satisfied until he knew how the bird or animal related to others of its kind, what it fed upon, its comings and goings, how it lived and how it died.

Through a well-developed skill as a wildlife photographer Larry could show others how he felt about nature. How a pair of foxes raised their kits, 


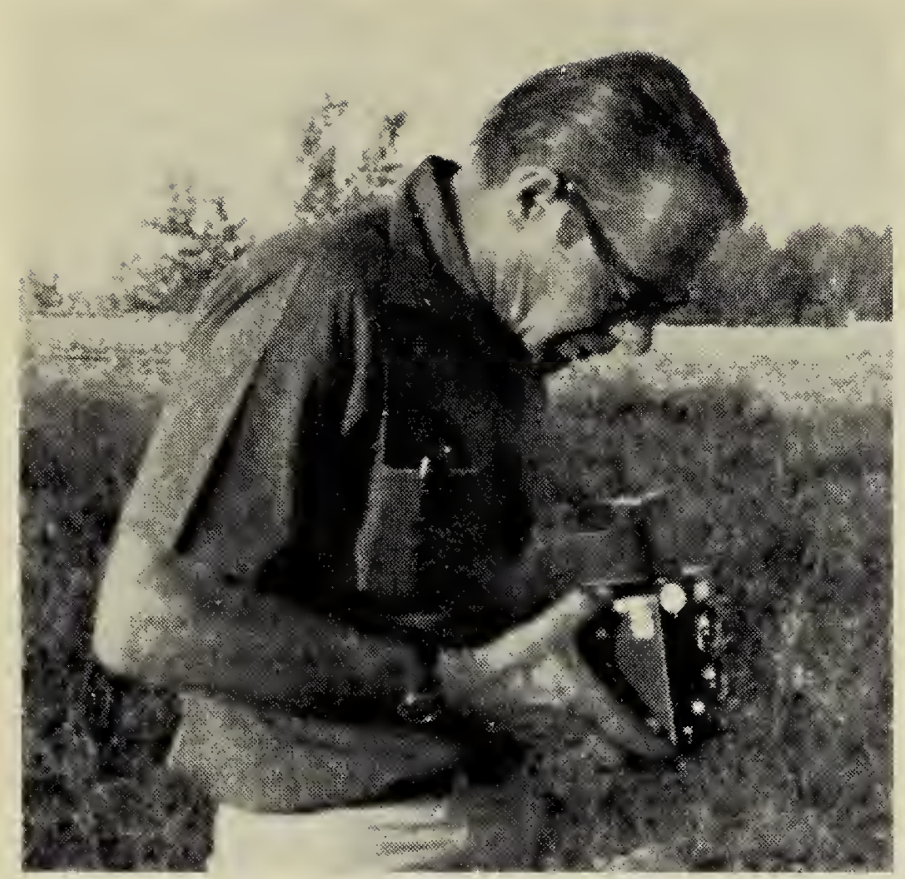

Larry Morgotch

Ralph Morgotch

how a Great Blue Heron colony functioned, how the muskrat lived, how a Great Horned Owl protected her eggs through March blizzards. I mention only a few examples, for it would take a whole volume to describe Larry's many picture stories.

Field trips with Larry were never a dead loss. If bird or animal photography was not productive, he would observe and if that was not satisfactory, he would find interest in something else. Often this meant heading for some open field where soil had been eroded. There, crossing and re-crossing the terrain, he would usually find native artifacts. Larry's collection of arrowheads, scrapers and stone hammers gave him great satisfaction. Invariably, upon making a find, he would puzzle about the person who made it and how it had been used. These scattered artifacts found in open fields tell little about the hunt. They do, however, indicate the culture of the person who did the manufacturing.

Larry was active in wildlife and conservation societies. He was a member of the Yorkton branch of the
Saskatchewan Wildlife Federation He was also one of the guiding hand that reactivated the Yorkton Natur History Society in the 1960's, and h was always a staunch supporter the Saskatchewan Natural Histor Society. The last occasion that spent time in the field with Larry wa at the S.N.H.S. summer meet a Eastend. Since moving away fron Yorkton I had not had the opportunit to walk, look, and talk with Larry. W spent considerable time along wit other friends on that occasio watching Prairie Falcons at an eyrie It was while sitting on a hill watchin the falcons that we decided that $w$ should get together in the spring $c$ 1980 and come back to the Easten country to photograph Sage Grouse That plan was never to be carrie out.

I spent several evenings i Saskatoon with Larry in a Universit Hospital room in December 1979. was then that we realized that $w$ would not sit together on some sage covered knoll in the spring. We woul never be able to squint through ou telephoto-equipped cameras an together picture the courtship ac tivities of the Sage Grouse.

On 28 January 1980 cance claimed Larry's life, but it did nc claim his memory or his soul. Th first lines of the Twenty-third Psalr printed in his funeral card are mos appropriate:

The Lord is my shepherd, I shall not wan He maketh me to lie down in gree pastures; He leadeth me beside the sti waters. He restoreth my soul....

Larry is survived by his wif Delores, his son Ralph, his Mothe and sisters Irma, Sandra, Beatric and Roslyn. He will be remembere by his many friends in the Yorkto and Saskatchewan Natural Histor Societies. 